\title{
Experimental Modeling of Ankerite-Pyrite Interaction under Lithospheric Mantle P-T Parameters: Implications for Graphite Formation as a Result of Ankerite Sulfidation
}

\author{
Yuliya V. Bataleva ${ }^{1, *(\mathbb{D}}$, Ivan D. Novoselov ${ }^{1,2} \mathbb{D}$, Yuri M. Borzdov ${ }^{1}$, Olga V. Furman ${ }^{1,2}$ and Yuri N. Palyanov ${ }^{1,2, *}$ \\ 1 Sobolev Institute of Geology and Mineralogy, Siberian Branch of Russian Academy of Sciences, \\ 630090 Novosibirsk, Russia; novoselovid@igm.nsc.ru (I.D.N.); borzdov@igm.nsc.ru (Y.M.B.); \\ furmano@igm.nsc.ru (O.V.F.) \\ 2 Department of Geology and Geophysics, Novosibirsk State University, 630090 Novosibirsk, Russia \\ * Correspondence: bataleva@igm.nsc.ru (Y.V.B.); palyanov@igm.nsc.ru (Y.N.P.); Tel.: +7-383-330-75-01 (Y.N.P.)
}

\section{check for} updates

Citation: Bataleva, Y.V.; Novoselov I.D.; Borzdov, Y.M.; Furman, O.V.;

Palyanov, Y.N. Experimental

Modeling of Ankerite-Pyrite

Interaction under Lithospheric

Mantle P-T Parameters: Implications for Graphite Formation as a Result of Ankerite Sulfidation. Minerals 2021, 11, 1267. https://doi.org/10.3390/ $\min 11111267$

Academic Editor: Yoichi Nakajima

Received: 18 September 2021

Accepted: 12 November 2021

Published: 14 November 2021

Publisher's Note: MDPI stays neutral with regard to jurisdictional claims in published maps and institutional affiliations.

Copyright: (c) 2021 by the authors. Licensee MDPI, Basel, Switzerland. This article is an open access article distributed under the terms and conditions of the Creative Commons Attribution (CC BY) license (https:/ / creativecommons.org/licenses/by/ $4.0 /)$.

\begin{abstract}
Experimental modeling of ankerite-pyrite interaction was carried out on a multi-anvil high-pressure apparatus of a "split sphere" type (6.3 GPa, $\left.1050-1550{ }^{\circ} \mathrm{C}, 20-60 \mathrm{~h}\right)$. At $\mathrm{T} \leq 1250{ }^{\circ} \mathrm{C}$, the formation of pyrrhotite, dolomite, magnesite, and metastable graphite was established. At higher temperatures, the generation of two immiscible melts (carbonate and sulfide ones), as well as graphite crystallization and diamond growth on seeds, occurred. It was established that the decrease in iron concentration in ankerite occurs by extraction of iron by sulfide and leads to the formation of pyrrhotite or sulfide melt, with corresponding ankerite breakdown into dolomite and magnesite. Further redox interaction of $\mathrm{Ca}, \mathrm{Mg}$,Fe carbonates with pyrrhotite (or between carbonate and sulfide melts) results in the carbonate reduction to $\mathrm{C}^{0}$ and metastable graphite formation ( \pm diamond growth on seeds). It was established that the ankerite-pyrite interaction, which can occur in a downgoing slab, involves ankerite sulfidation that triggers further graphite-forming redox reactions and can be one of the scenarios of the elemental carbon formation under subduction settings.
\end{abstract}

Keywords: graphite formation; ankerite; pyrite; sulfidation; mantle sulfides; high-pressure experiment; lithospheric mantle; experimental modeling

\section{Introduction}

The existing ideas about the polygenic origin of diamond [1-3] imply various processes, mechanisms, and driving forces of diamond crystallization in nature, including redox reactions, changes in $\mathrm{P}-\mathrm{T}$ conditions, the evolution of melt or fluid composition, etc. [1-8]. According to existing models, diamond formation in the lithospheric mantle occurs at depths of $120-210 \mathrm{~km}$ and at temperatures of $900-1500{ }^{\circ} \mathrm{C}$, as a result of metasomatic processes. Redox reactions leading to the oxidation of hydrocarbons or the reduction of carbonates or $\mathrm{CO}_{2}$ to elemental carbon are considered as driving forces of diamond formation in these models $[3,9,10]$. Other models include the formation of diamonds as a result of decompression or cooling of fluids, partial melting in the presence of fluid [11], electrochemical processes (the effect of an electric field on carbonate or carbonate-silicate melts, [12]), or mixing of various fluids or melts [13].

The main evidence for the genetic relationship of some natural diamonds with carbonates is, first, carbonate inclusions [14-18] and fluid inclusions, for which an essential carbonatite composition is reported [19-26], in diamonds of the upper and lower mantle genesis. Secondly, the so-called subduction isotope signature of some natural diamonds, which consists of variations in the $\delta^{13} \mathrm{C}$ values of diamond, has been found to exist close to $\delta^{13} \mathrm{C}$ of subducted carbonates [27]. Currently, it is known that some carbonates are thermodynamically stable up to P-T parameters of the lower mantle [28], and under subduction conditions, up to $80 \%$ of carbonates do not undergo decarbonation and partial 
melting (Figure 1) [29,30], and they can be transported to depths over $600 \mathrm{~km}[2,3,31]$ and, accordingly, participate in the processes of diamond genesis at mantle depths.

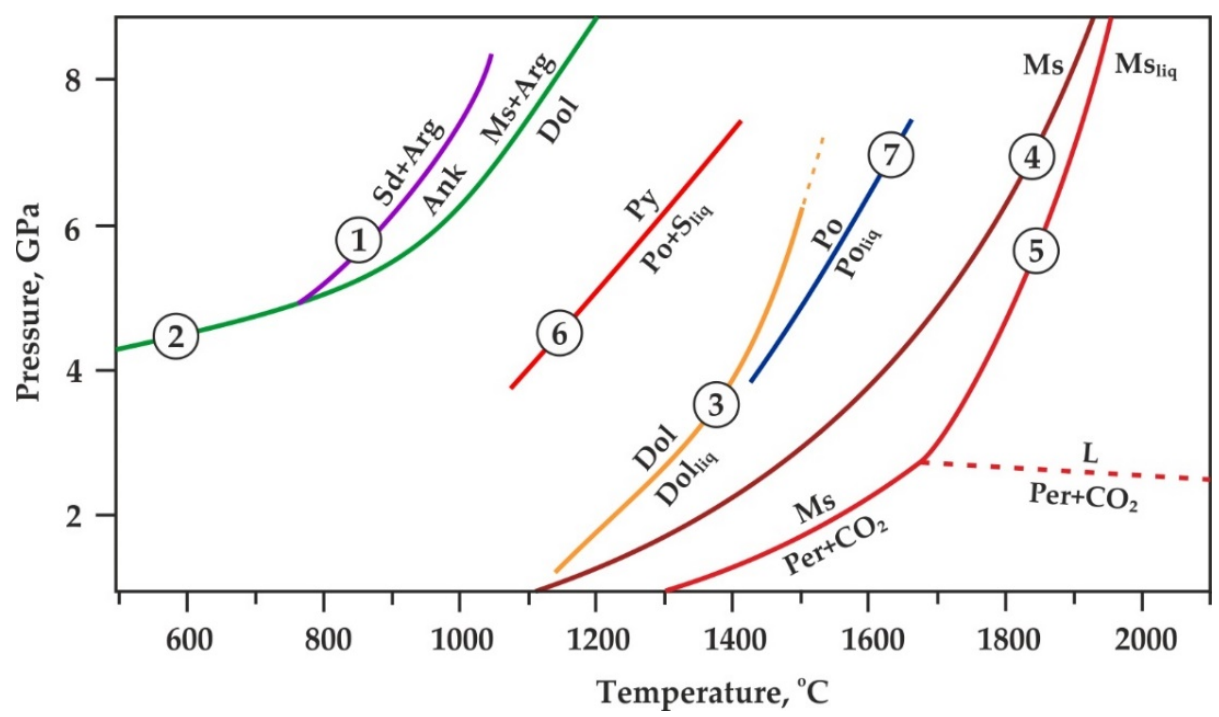

Figure 1. Experimentally determined parameters of melting and decomposition of $\mathrm{Mg}, \mathrm{Ca}, \mathrm{Fe}$ carbonates and iron sulfides: 1 -siderite + aragonite $=$ ankerite [31]; 2-magnesite + aragonite $=$ dolomite [31]; 3-dolomite melting [32]; 4,5-magnesite melting and decomposition [33]; 6,7-pyrite and pyrrhotite melting curves [34]. Dotted line denotes P-T position of reaction of periclase $+\mathrm{CO}_{2}=\mathrm{MgCO}_{3}$ melt [33].

Existing experimental studies of the formation of diamond and graphite from the carbon of carbonates (or $\mathrm{CO}_{2}$-fluid) as a result of redox reactions (Figure 2) were carried out with the participation of $\mathrm{Si}, \mathrm{SiC}$, silicon-bearing alloys [35,36], methane-aqueous, or hydrogen fluids [37,38], metallic iron and cohenite [6,39], as well as sulfides [40-42]. The obtained data confirmed the fundamental possibility of diamond formation by reduction of carbonate in nature, while it is assumed that in the lithospheric mantle at depths insufficient for the stabilization of metallic iron or carbides, the most probable reducing agents are Fe,Ni sulfides.

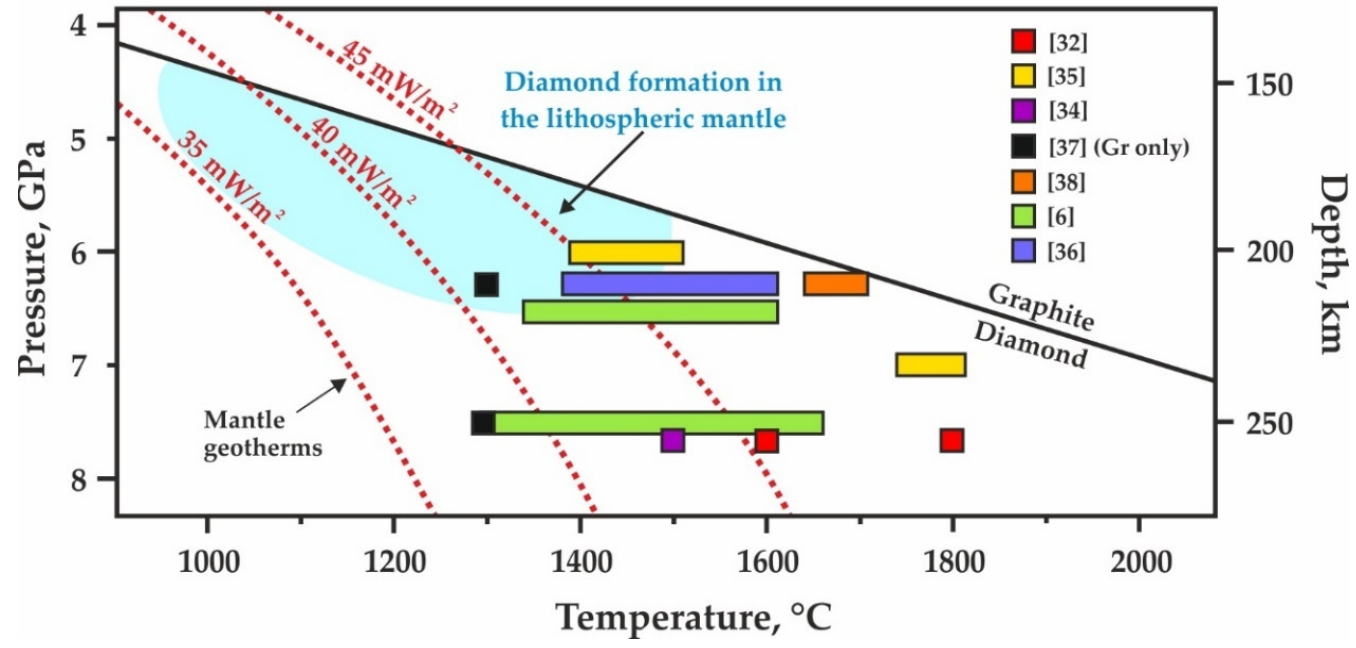

Figure 2. Experimentally determined P-T parameters of spontaneous diamond nucleation as a result of carbonate reduction. Additionally, the parameters of the formation of graphite as a result of carbonate reduction by the Fe-S-O melt are given. 
Despite the fact that the fundamental possibility of the formation of diamond and graphite by reduction of carbonate $/ \mathrm{CO}_{2}$-fluid with sulfides or sulfide melts has already been experimentally demonstrated, there are still a number of unresolved issues in this direction. In particular, our recent experimental studies in multicomponent $\mathrm{Fe}$,Ni-olivineankerite-sulfur and $\mathrm{Fe}, \mathrm{Ni}$-olivine-ankerite-pyrite systems [43], aimed at modeling the reactions of silicates and carbonates sulfidation, showed the possibility of crystallization of elemental carbon (graphite) in these processes. However, due to the complexity of the studied systems, a detailed reconstruction of the formation processes of elemental carbon phases during sulfidation of FeO-bearing carbonates was not possible. In this regard, in this study, it seems relevant to investigate the processes of formation of graphite ( \pm diamond), coupled with sulfidation of carbonate, in a relatively simple ankerite-pyrite system at P-T parameters of the lithospheric mantle.

\section{Materials and Methods}

Experimental modeling of the graphite-producing carbonate-sulfide interaction was carried out in the ankerite-pyrite system $\left(\mathrm{Ca}(\mathrm{Fe}, \mathrm{Mg})\left(\mathrm{CO}_{3}\right)_{2}-\mathrm{FeS}_{2}\right)$ on a multi-anvil highpressure apparatus of a "split sphere" type (BARS) [44], at a pressure of $6.3 \mathrm{GPa}$, in the temperature range of $1050-1550{ }^{\circ} \mathrm{C}$ (with a step of $100{ }^{\circ} \mathrm{C}$ ) and durations from 20 to $60 \mathrm{~h}$. Methodological features of the assembly, high-pressure cell schemes, as well as data on the calibration were published earlier [44-46]. The starting reagents were natural ankerite $\left(\mathrm{CaFe}_{0.49} \mathrm{Mg}_{0.49} \mathrm{Mn}_{0.02}\left(\mathrm{CO}_{3}\right)_{2}\right.$, Kyshtym deposit, Urals, Russia), and pyrite $\left(\mathrm{FeS}_{2}\right.$, Astafyevskoe deposit, Urals, Russia). The weight proportions of the original ankerite and pyrite were 56.7 and $10.5 \mathrm{mg}$, respectively. The proportions of ankerite and pyrite were chosen on the basis that with the complete extraction of iron by the sulfide phase from carbonate, the obtained sulfide would have the stoichiometry of pyrrhotite (according to reaction Ank $+\mathrm{Py}=\mathrm{Dol}+\mathrm{Mg}$, Ca carbonate $+\mathrm{Po})$. Considering the impossibility of studying sulfides and sulfur-bearing phases in Pt ampoules at mantle pressures and temperatures $[36,38,47]$, graphite was selected as the optimal material for the capsules; in addition, the graphite material of the capsules ensured the maintenance of oxygen fugacity in the reaction volume below the $\mathrm{CCO}\left(\mathrm{C}+\mathrm{O}_{2}=\mathrm{CO}_{2}\right)$ buffer equilibrium (FMQ +1 log units) during experiments [38], which are considered to be average for the lithospheric mantle.

Given the studied processes result in the formation of elemental carbon, control experiments were performed, using alternative capsule materials (talc ceramics and $\mathrm{MgO}$ ), with no diamond seeds, to evaluate the effect of the graphite capsule material on phase formation processes. The experiments showed that products of the ankerite-pyrite interaction reacted both with $\mathrm{MgO}$ and talc ceramics (Table 1, Figure 3), with a significant loss of iron in the system. However, despite the fact that $\mathrm{MgO}$ and talc ceramics capsules were unsuitable for the accurate study of ankerite-pyrite interaction processes, their use demonstrated the effectiveness of ankerite-pyrite interaction in graphite crystallization in the presence of carbonate (ankerite) as the only carbon source.

Table 1. Experimental parameters and results obtained in the ankerite-pyrite system (pressure 6.3 GPa).

\begin{tabular}{|c|c|c|c|c|c|}
\hline Run No. & $\mathrm{T},{ }^{\circ} \mathrm{C}$ & $t, h$ & Capsule Material & Phase Assemblage & Diamond Growth on Seeds \\
\hline $932-4$ & 1050 & 60 & Gr & Ms, Dol, Py, Po, Gr & no \\
\hline $1476-4$ & 1150 & 60 & $\mathrm{Gr}$ & Ms, Dol, Py, Po, Gr & no \\
\hline $1997-4$ & 1250 & 60 & $\mathrm{Gr}$ & Ms, Dol, Po, Py, Gr & no \\
\hline $2000-4$ & 1350 & 20 & $\mathrm{Gr}$ & Ms, Dol, Gr, Carb liq, Sulf ${ }_{\text {liq }}$ & yes \\
\hline 2001-4 & 1450 & 20 & $\mathrm{Gr}$ & Ms, Gr, Carb ${ }_{\text {liq }}$, Sulf liq & yes \\
\hline $1811-4$ & 1550 & 20 & Gr & Gr, Carb ${ }_{\text {liq, }}$, Sulf liq & yes \\
\hline 2002-M & 1350 & 20 & $\mathrm{MgO}$ & Carb $_{\text {lig, }}$, Sulf ${ }_{\text {liq }}, \mathrm{Gr}$ & No seeds \\
\hline 2003-M & 1450 & 20 & $\mathrm{MgO}$ & Carb $_{\text {liq, }}$, Sulf ${ }_{\text {liq, }}$, Gr & No seeds \\
\hline 2004-T & 1550 & 20 & Ta ceramics & Ol, Carb ${ }_{\text {liq, }}$, Sulf ${ }_{\text {liq }}$, Gr & No seeds \\
\hline
\end{tabular}

Ms—magnesite; Dol—dolomite; Gr—graphite; Py—pyrite; Po—pyrrhotite; Carb liq—carbonate melt; Sulf ${ }_{\text {liq }}$-sulfide melt; Ta—talc; Ol—olivine. 


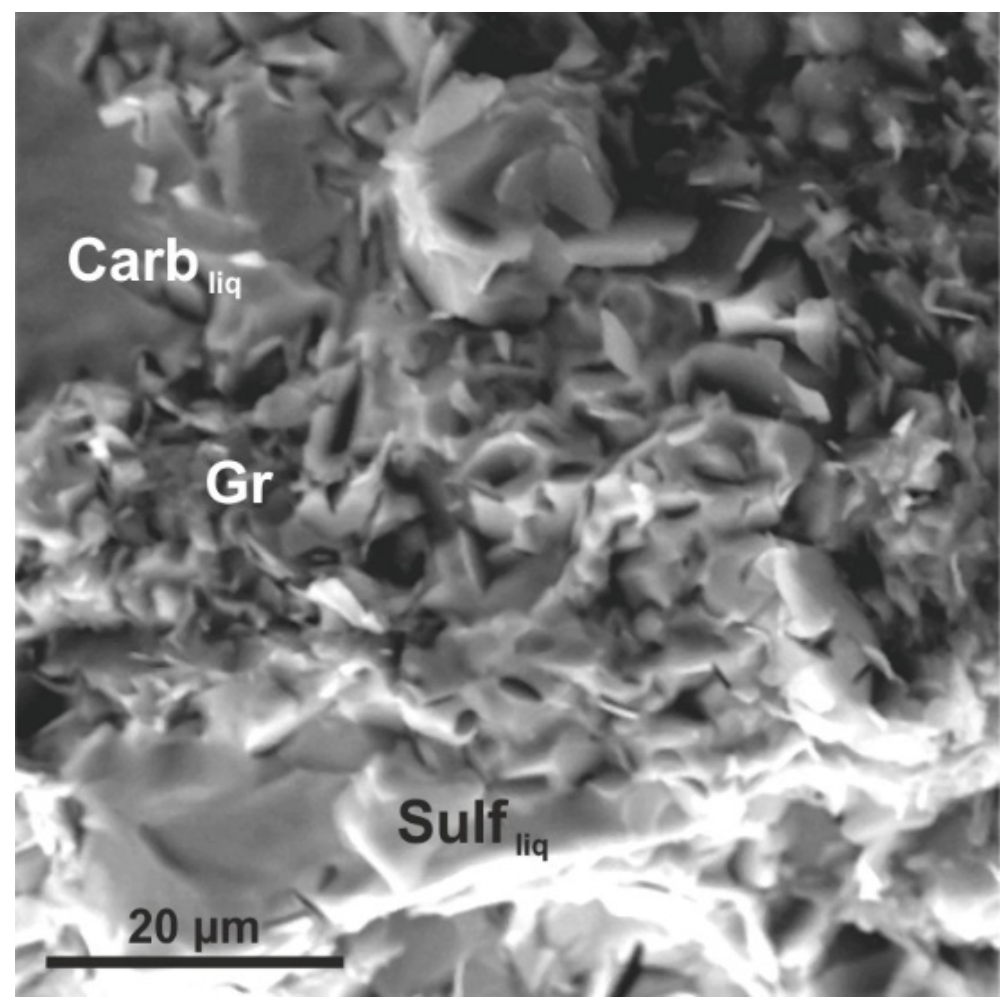

Figure 3. SEM micrograph (BSE regime) of cleavage surface of the sample from the experiment with $\mathrm{MgO}$ capsules, illustrating graphite formation in the presence of a single one-carbon source (run \# 2003-M, $\left.1450{ }^{\circ} \mathrm{C}\right)$.

Initial reagents were thinly powdered and thoroughly homogenized. Three seed diamond crystals of cuboctahedral habit $(\sim 500 \mu \mathrm{m}$ in size) were placed in the reaction volume of the capsules to obtain information on the possibility of diamond growth at $\mathrm{P}, \mathrm{T}$, $f \mathrm{O}_{2}$, x-parameters of the experiments.

Optical examination of the experimental samples was carried out on stereomicroscopes "Stemi 508" and "Axio Imager 2" (Carl Zeiss Microscopy, Jena, Germany). The phase and chemical compositions of the samples, as well as phase relationships, were studied by scanning electron microscopy and energy dispersive spectroscopy (TESCAN MIRA 3 LMU, Tescan, Brno, Czech Republic), as well as microprobe analysis (Jeol JXA-8100, JEOL Ltd., Tokyo, Japan). The analysis of carbonate and sulfide phases was carried out at an accelerating voltage of $20 \mathrm{kV}$, a probe current of $20 \mathrm{nA}$, a counting time of $10 \mathrm{~s}$ on each analytical line, and an electron beam diameter of $3 \mu \mathrm{m}$. To analyze the compositions of quenched melts-sulfide and carbonate, which are represented by aggregates of microdendrites, the electron beam diameter was increased to $20-40 \mu \mathrm{m}$. To study the morphology of diamond seed crystals, the method of differential interference contrast microscopy (microscope "Axio Imager 2", Carl Zeiss Microscopy, Jena, Germany) and scanning electron microscopy were used. Raman spectroscopy was used to study the structural features of carbonates, sulfides, and graphite (Jobin Yvon LabRAM HR800 spectrometer, Horiba, Tokyo, Japan, equipped with an Olympus BX41 stereo microscope, Horiba Jobin Yvon S.A.S., Lonjumeau, France). A He-Cd laser with a wavelength of $325 \mathrm{~nm}$ is used as an excitation source. Analytical studies were carried out at the V.S. Sobolev Institute of Geology and Mineralogy SB RAS and the Center for Collective Use of Multi-Element and Isotopic Analysis of the Siberian Branch of Russian Academy of Sciences.

\section{Results}

The parameters and results of the experiments are shown in Table 1. It should be noted that the experiments are conditionally divided into relatively low-temperature 
(1050-1250 $\left.{ }^{\circ} \mathrm{C}, 60 \mathrm{~h}\right)$, in which pyrite is stable in the form of a solid phase, and hightemperature $\left(1350-1550{ }^{\circ} \mathrm{C}, 20 \mathrm{~h}\right.$ ), in which pyrite undergoes incongruent melting according to the reaction $\mathrm{FeS}_{2} \rightarrow \mathrm{FeS}+\mathrm{S}_{\text {liq }}$ (Figure 1). In the ankerite-pyrite system at relatively low temperatures $\left(1050-1250{ }^{\circ} \mathrm{C}\right)$, the crystallization of newly formed pyrrhotite $\mathrm{Fe}_{0.88} \mathrm{~S}$, dolomite $\mathrm{Ca}_{0.91-0.97} \mathrm{Mg}_{0.67-0.96} \mathrm{Fe}_{0.02-0.31}\left(\mathrm{CO}_{3}\right)_{2}$, magnesite $\mathrm{Mg}_{0.85-0.89} \mathrm{Ca}_{0.06-0.09} \mathrm{Fe}_{0.01} \mathrm{CO}_{3}$ and metastable graphite was established, as well as a part of the initial pyrite retained in the samples (Figure 4a, Tables 2 and 3). There is no ankerite presented in the samples. The structure of the samples obtained is shown in Figure 5a,b. Raman spectra of starting and final carbonates and sulfides, as well as graphite, are shown in Figures 6 and 7. Pyrrhotite crystals are, in most cases, spatially confined to pyrite; at $1050-1150{ }^{\circ} \mathrm{C}$, they either form reaction rims around pyrite or are in intergrowth with it, and at $1250{ }^{\circ} \mathrm{C}$, pyrrhotite also occurs in the form of monomineralic aggregates. It should be noted that crystals of metastable graphite are also spatially confined to sulfides and are located at the contact of sulfides with carbonates. In some large $(\sim 100 \mu \mathrm{m})$ crystals of FeO-bearing dolomite, zoning is noted, with a high-iron center and a low- or iron-free periphery rims. With an increase in temperature within the range of $1050-1250{ }^{\circ} \mathrm{C}$, an increase in the amount of pyrrhotite and graphite occurs (Figure 5a,b), and the composition of the resulting phases also changes. In particular, for dolomite, a tendency for $\mathrm{FeO}$ concentration to decrease from $11.5 \mathrm{wt}$ \% $\left(1050{ }^{\circ} \mathrm{C}\right)$ to $0.7 \mathrm{wt} . \%\left(1350{ }^{\circ} \mathrm{C}\right)$ occurs.

Raman spectroscopic study of the obtained dolomite and magnesite showed that the main Raman modes for them are 173, 296, 724, and $1097 \mathrm{~cm}^{-1}$ and 210, 327, 737, and $1094 \mathrm{~cm}^{-1}$, respectively (Figure 6a). Sulfides have peaks at 216, 277, 390 and $589 \mathrm{~cm}^{-1}$ (pyrrhotite) and at 346, 381 and $434 \mathrm{~cm}^{-1}$ (pyrite) (Figure 6b). In the Raman spectra of graphite, intense bands of the first order $D\left(1359 \mathrm{~cm}^{-1}\right), G\left(1581 \mathrm{~cm}^{-1}\right)$, and $\mathrm{D}^{\prime}\left(1624 \mathrm{~cm}^{-1}\right)$, as well as the second-order- $\mathrm{G}^{\prime}\left(2718 \mathrm{~cm}^{-1}\right)$ (Figure 7). It should be noted that the most characteristic feature of the obtained graphite is the defectiveness of its structure, as evinced by the increased intensity of the "defect" $\mathrm{D}$ and $\mathrm{D}$ ' bands. We believe that the main reason for the defectiveness of graphite is the fact that graphite aggregates were found exclusively at the contact of sulfide melt drops with carbonate melt, and their crystallization area was restricted with this surface. Most probably, graphite aggregate consisted of variously oriented clusters or microcrystals, and it reflected in Raman spectra.

It was found that the interaction of ankerite with pyrite at relatively high temperatures $\left(1350-1550{ }^{\circ} \mathrm{C}\right)$ leads to the formation of dolomite, magnesite ( \pm magnesian aragonite), the generation of sulfide and carbonate melts, as well as the crystallization of metastable graphite and the growth of diamond on seed crystals (Figure $4 \mathrm{~b}-\mathrm{f}$ ). The schematic structure of the obtained samples is shown in Figure $5 \mathrm{c}-\mathrm{e}$. At $1350^{\circ} \mathrm{C}$, the sample is represented by a coarse-crystalline aggregate of dolomite and magnesite, in which there are rounded drops of quenched sulfide melt and graphite crystals confined to them (Figures $4 b-d$ and $5 c$ ). The interstitions of the carbonate matrix contain a small amount of high-calcium (Ca \# 0.71) carbonate melt. The initial stage of diamond growth was established on seed crystals at a given temperature. At $1450{ }^{\circ} \mathrm{C}$, the upper and central parts of the sample contain a quenched carbonate melt, and the lower part of the sample contains magnesite aggregate with carbonate melt in the interstices, droplets of quenched sulfide melt, and graphite crystals (Figures $4 \mathrm{e}$ and $5 \mathrm{~d}$ ). At $1550{ }^{\circ} \mathrm{C}$, solid-phase carbonates are absent; the sample is completely represented by a quenched carbonate melt, which contains drops of sulfide melt (up to $1 \mathrm{~mm}$ in diameter) and large plate crystals of graphite (up to $100 \mu \mathrm{m}$ ). At $\geq 1450{ }^{\circ} \mathrm{C}$, the formation of an overgrown diamond layer with a thickness of up to $70 \mu \mathrm{m}$ on the $\{111\}$ and $\{100\}$ faces was established on the seed crystals (Figure $4 \mathrm{f}$ ). 

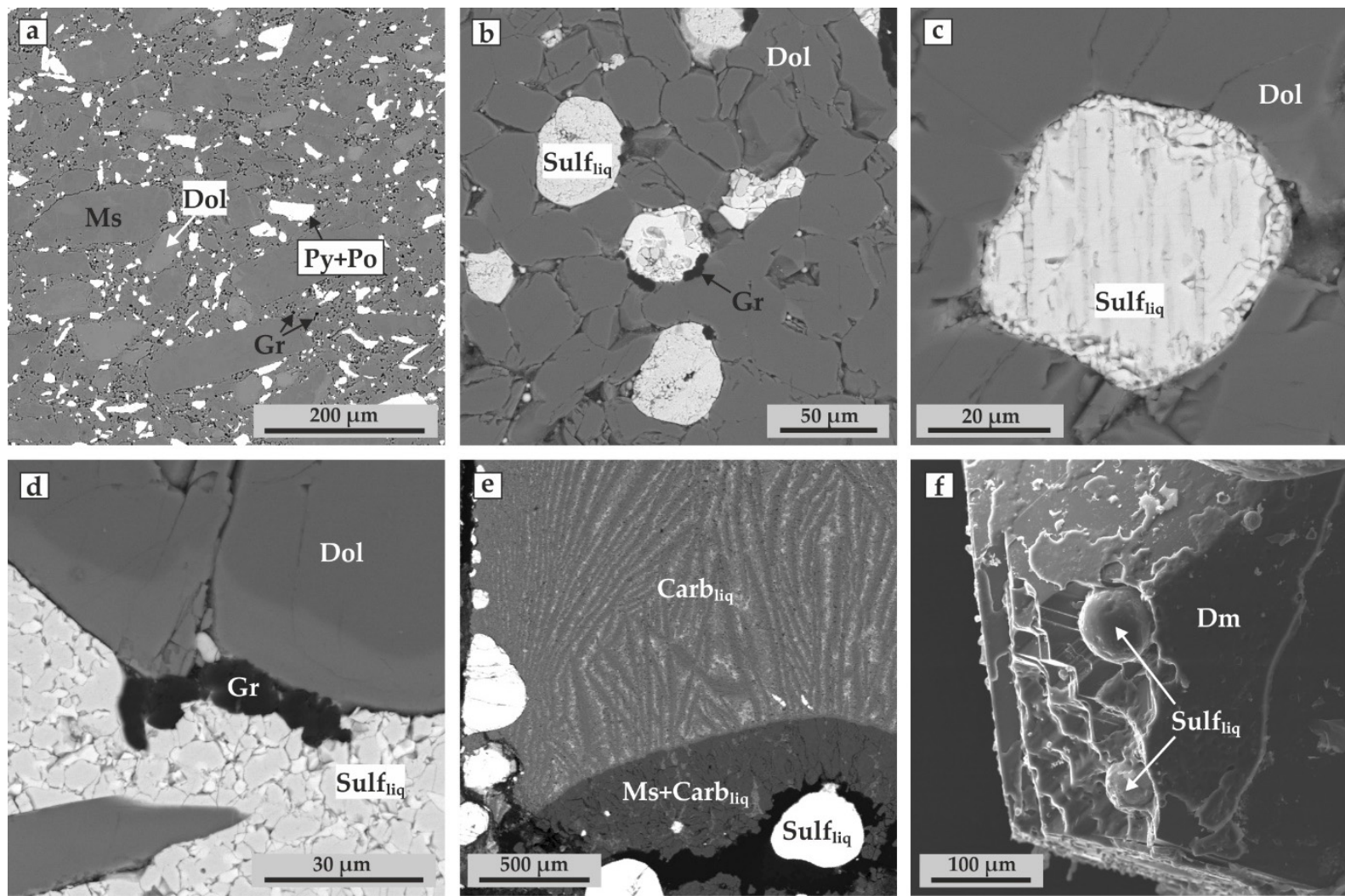

Figure 4. SEM-micrographs (BSE regime) of polished sample fragments and diamond seed crystal, after experiments in ankerite-pyrite system: (a) polycrystalline aggregate of dolomite, magnesite, pyrite, pyrrhotite, and graphite (run No. 932-4); (b) polycrystalline aggregate of dolomite with drops of quenched sulfide melt and graphite crystals (run No. 2000-4); (c) drop of quenched sulfide melt in dolomite aggregate (run No. 2000-4); (d) zonal dolomite crystals at the contact with quenched sulfide melt and graphite crystals (run No. 2000-4); (e) quenched carbonate and sulfide melt, as well as magnesite polycrystalline aggregate (run No. 2001-4); (f) diamond seed crystal with growth layers and sulfide melt droplets (run No. 1181-4). Ms—magnesite; Dol—dolomite; Gr—graphite; Py—pyrite; Po-pyrrhotite; Carb liq—carbonate melt; Sulf liq - sulfide melt; Dm—diamond seed crystals.

Table 2. Averaged compositions of carbonates and carbonate melts.

\begin{tabular}{|c|c|c|c|c|c|c|c|c|c|c|c|c|c|c|}
\hline \multirow{2}{*}{ Run No. } & \multirow{2}{*}{$\mathrm{T},{ }^{\circ} \mathrm{C}$} & \multirow{2}{*}{ Phase } & \multirow{2}{*}{$\mathbf{N}_{\mathrm{A}}$} & \multicolumn{5}{|c|}{ Composition, wt \% } & \multirow{2}{*}{$\mathbf{n}(\mathrm{O})$} & \multicolumn{5}{|c|}{ Cations per Formula Unit (p.f.u.) } \\
\hline & & & & $\mathrm{FeO}$ & $\mathrm{MgO}$ & $\mathrm{CaO}$ & $\mathrm{CO}_{2} *$ & Total & & $\mathrm{Fe}$ & $\mathrm{Mg}$ & $\mathrm{Ca}$ & $C * *$ & $\sum$ cat \\
\hline $\mathrm{n} / \mathrm{a}$ & $\mathrm{n} / \mathrm{a}$ & $\begin{array}{l}\text { Initial } \\
\text { ankerite }\end{array}$ & 12 & 18.6 & 9.8 & 27.0 & 43.9 & 99.3 & 6 & 0.49 & 0.49 & 1 & 2 & 3.98 \\
\hline \multirow{3}{*}{932} & \multirow{3}{*}{1050} & Ms & 10 & 0.8 & 41.6 & 3.8 & 53.8 & 100.0 & 3 & 0.01 & 0.89 & 0.06 & 1 & 1.98 \\
\hline & & Dol & 10 & 2.6 & 20.3 & 27.9 & 49.2 & 100.0 & 6 & 0.07 & 0.92 & 0.91 & 2.05 & 3.95 \\
\hline & & Dol & 10 & 11.5 & 14.0 & 27.6 & 46.4 & 100.0 & 6 & 0.31 & 0.67 & 0.95 & 2.03 & 3.96 \\
\hline \multirow{2}{*}{1476} & \multirow{2}{*}{1150} & Ms & 7 & $0.6_{(3)}$ & $40.1_{(5)}$ & $6_{(1)}$ & $52.9_{(5)}$ & 100.0 & 3 & $0.010_{(5)}$ & $0.85_{(1)}$ & $0.09_{(2)}$ & $1.02_{(1)}$ & 1.97 \\
\hline & & Dol & 10 & $0.7_{(4)}$ & $20.9_{(9)}$ & $29_{(1)}$ & $48_{(1)}$ & 100.0 & 6 & $0.02_{(1)}$ & $0.96_{(4)}$ & $0.97_{(5)}$ & $2.05_{(1)}$ & 3.98 \\
\hline 1997 & 1250 & Dol & 25 & $3.0_{(5)}$ & $19.8_{(5)}$ & $28.4_{(4)}$ & $48.2_{(7)}$ & 100.0 & 6 & $0.08_{(1)}$ & $0.91_{(2)}$ & $0.94_{(2)}$ & $2.03_{(2)}$ & 3.96 \\
\hline \multirow{2}{*}{2000} & \multirow{2}{*}{1350} & Dol & 16 & $2.7_{(4)}$ & $22.0_{(4)}$ & $26.1_{(6)}$ & $49.0_{(6)}$ & 100.0 & 6 & $0.07_{(1)}$ & $1.00(2)$ & $0.85_{(2)}$ & $2.04_{(2)}$ & 3.96 \\
\hline & & $\begin{array}{c}\text { Carb } \\
\text { liq }\end{array}$ & 18 & $1.8_{(6)}$ & $13_{(1)}$ & $37.5_{(9)}$ & $47.6_{(4)}$ & 100.0 & - & - & - & - & - & - \\
\hline \multirow{2}{*}{2001} & \multirow{2}{*}{1450} & Ms & 12 & $1.7_{(2)}$ & $40.9_{(1)}$ & $3.6_{(3)}$ & $53.8_{(8)}$ & 100.0 & 3 & $0.02_{(0)}$ & $0.86_{(0)}$ & $0.05_{(0)}$ & $1.03_{(1)}$ & 1.97 \\
\hline & & $\begin{array}{c}\text { Carb } \\
\text { liq }\end{array}$ & 20 & $3.0_{(3)}$ & $15.6_{(7)}$ & $24.0_{(8)}$ & $57.4_{(9)}$ & 100.0 & - & - & - & - & - & - \\
\hline 1811 & 1550 & $\begin{array}{c}\text { Carb } \\
\text { liq }\end{array}$ & 24 & $6_{(2)}$ & $21_{(6)}$ & $17_{(3)}$ & $52_{(7)}$ & 100.0 & - & - & - & - & - & - \\
\hline
\end{tabular}

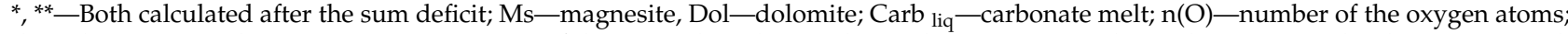
the values in parentheses are one sigma errors of the means based on replicate electron microprobe analyses reported as least units cited; $4.3_{(1)}$ should be read as $4.3 \pm 0.1 \mathrm{wt} \% ; \mathrm{N}_{\mathrm{A}}$-number of microprobe analyses; $\mathrm{n} / \mathrm{a}$-non-applicable; (-) p.f.u. calculations are not applicable to melts. 
Table 3. Averaged compositions of sulfides.

\begin{tabular}{|c|c|c|c|c|c|c|c|c|c|}
\hline \multirow{2}{*}{ Run No } & \multirow{2}{*}{$\mathrm{T},{ }^{\circ} \mathrm{C}$} & \multirow{2}{*}{ Phase } & \multirow{2}{*}{$\mathbf{N}_{\mathrm{A}}$} & \multicolumn{4}{|c|}{ Composition, wt \% } & \multicolumn{2}{|c|}{ Formula Units } \\
\hline & & & & $\mathrm{Fe}$ & $\mathrm{S}$ & $\mathrm{O}$ & Total & $\mathrm{Fe}$ & n (S) \\
\hline $\mathrm{n} / \mathrm{a}$ & $\mathrm{n} / \mathrm{a}$ & $\begin{array}{l}\text { Initial } \\
\text { pyrite }\end{array}$ & 10 & 46.8 & 53.0 & bdl & 99.8 & 1.00 & 2 \\
\hline \multirow{2}{*}{$932-4$} & \multirow{2}{*}{1050} & Po & 15 & $60.2_{(5)}$ & $39.6_{(5)}$ & bdl & 100.3 & $0.87_{(1)}$ & 1 \\
\hline & & Py & 18 & $46.3_{(3)}$ & $53.4_{(3)}$ & bdl & 100.1 & $1.00_{(1)}$ & 2 \\
\hline \multirow{2}{*}{$1476-4$} & \multirow{2}{*}{1150} & Po & 7 & $59_{(2)}$ & $39_{(2)}$ & bdl & 100.0 & $0.87_{(3)}$ & 1 \\
\hline & & Py & 5 & $46.7_{(2)}$ & $53.3_{(2)}$ & bdl & 100.0 & $1.01_{(1)}$ & 2 \\
\hline \multirow{2}{*}{$1997-4$} & \multirow{2}{*}{1250} & Po & 13 & $60.3_{(5)}$ & $39.1_{(7)}$ & bdl & 100.1 & $0.88_{(2)}$ & 1 \\
\hline & & Py & 15 & $45.6_{(3)}$ & $53.5_{(3)}$ & bdl & 100.0 & $0.98_{(1)}$ & 2 \\
\hline $2000-4$ & 1350 & Sulf $_{\text {liq }}$ & 37 & $60.9(5)$ & $39.7_{(6)}$ & $0.6_{(4)}$ & 100.9 & - & - \\
\hline 2001-4 & 1450 & Sulf $_{\text {liq }}$ & 18 & $60.8_{(6)}$ & $39.3_{(5)}$ & $1.3_{(6)}$ & 100.1 & - & - \\
\hline $1811-4$ & 1550 & Sulf $_{\text {liq }}$ & 22 & $63.1_{(5)}$ & $35_{(1)}$ & $2.0_{(5)}$ & 100.0 & - & - \\
\hline
\end{tabular}

Po-pyrrhotite; Py—-pyrite; Sulf liq —sulfide melt with dissolved oxygen; $\mathrm{n}(\mathrm{S})$ - number of the sulfur atoms in the formula; the values in parentheses are one sigma errors of the means based on replicate electron microprobe analyses reported as least units cited; $4.3_{(1)}$ should be read as $4.3 \pm 0.1 \mathrm{wt} \% ; \mathrm{N}_{\mathrm{A}}$-number of microprobe analyses; $\mathrm{n}$ /a—non-applicable; bdl: below detection limit; (-) formula unit calculations are not applicable to melts.

$\mathrm{T}=1050-1150{ }^{\circ} \mathrm{C}, \mathrm{t}=60$ hours

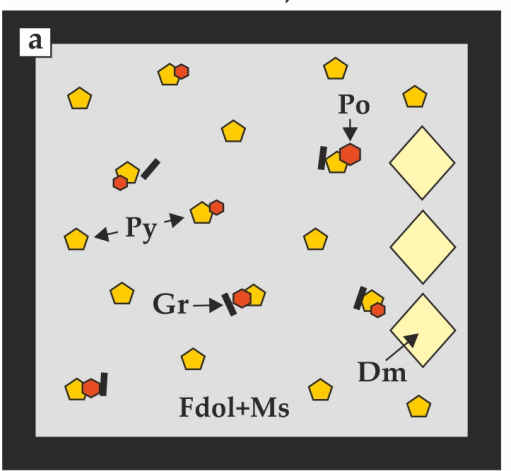

$\mathrm{T}=1250^{\circ} \mathrm{C}, \mathrm{t}=60$ hours
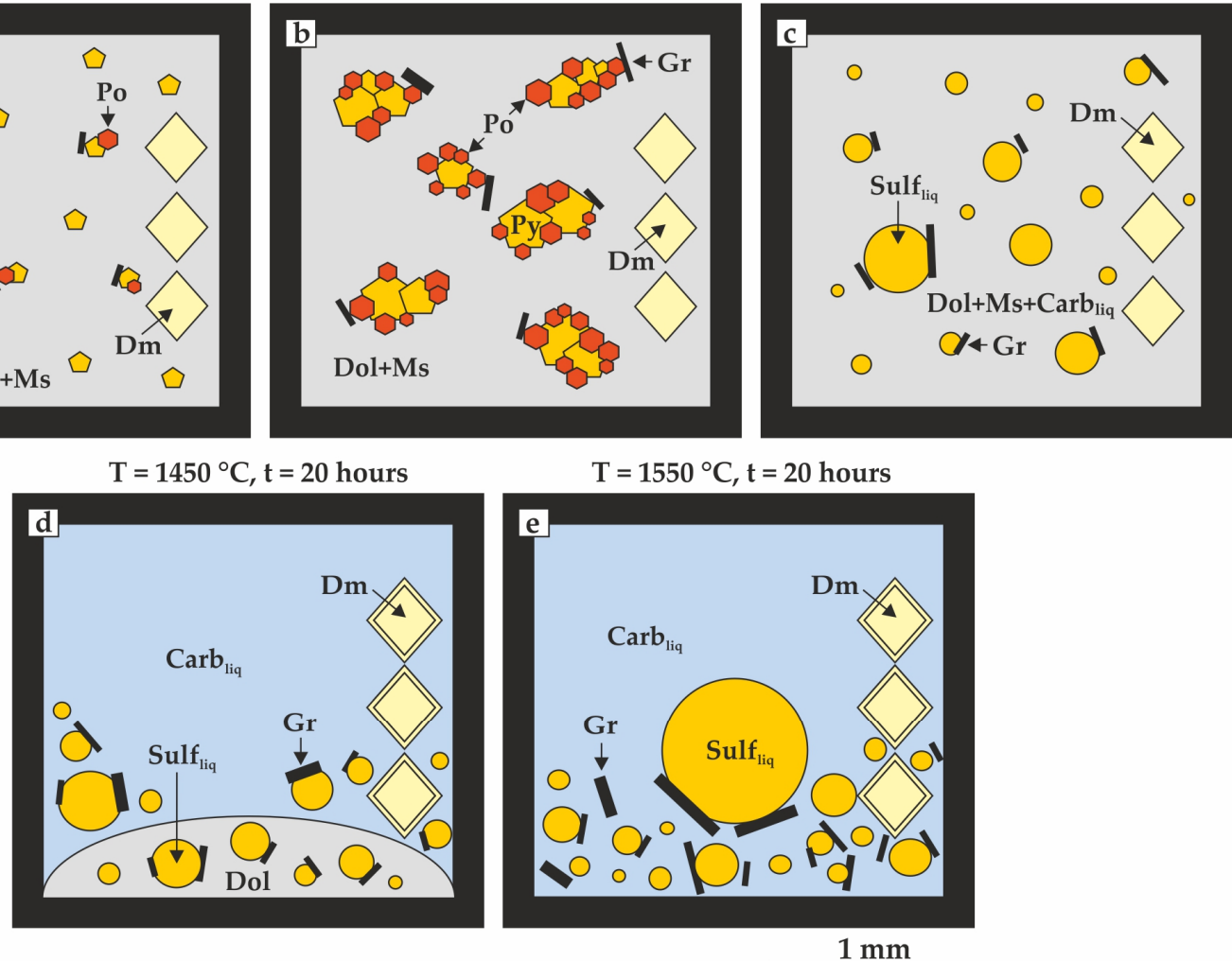

Figure 5. Schemes of samples produced in the ankerite-pyrite system at $6.3 \mathrm{GPa}$ in temperature range of $1050-1550{ }^{\circ} \mathrm{C}$;

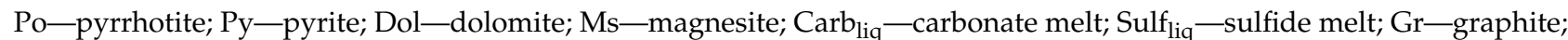
Dm-diamond seed crystals. (a) scheme for $1050-1150{ }^{\circ} \mathrm{C}$, (b) scheme for $1250{ }^{\circ} \mathrm{C}$, (c) scheme for $1350{ }^{\circ} \mathrm{C}$, (d) scheme for $1450{ }^{\circ} \mathrm{C}$ (e) scheme for $1550{ }^{\circ} \mathrm{C}$. 

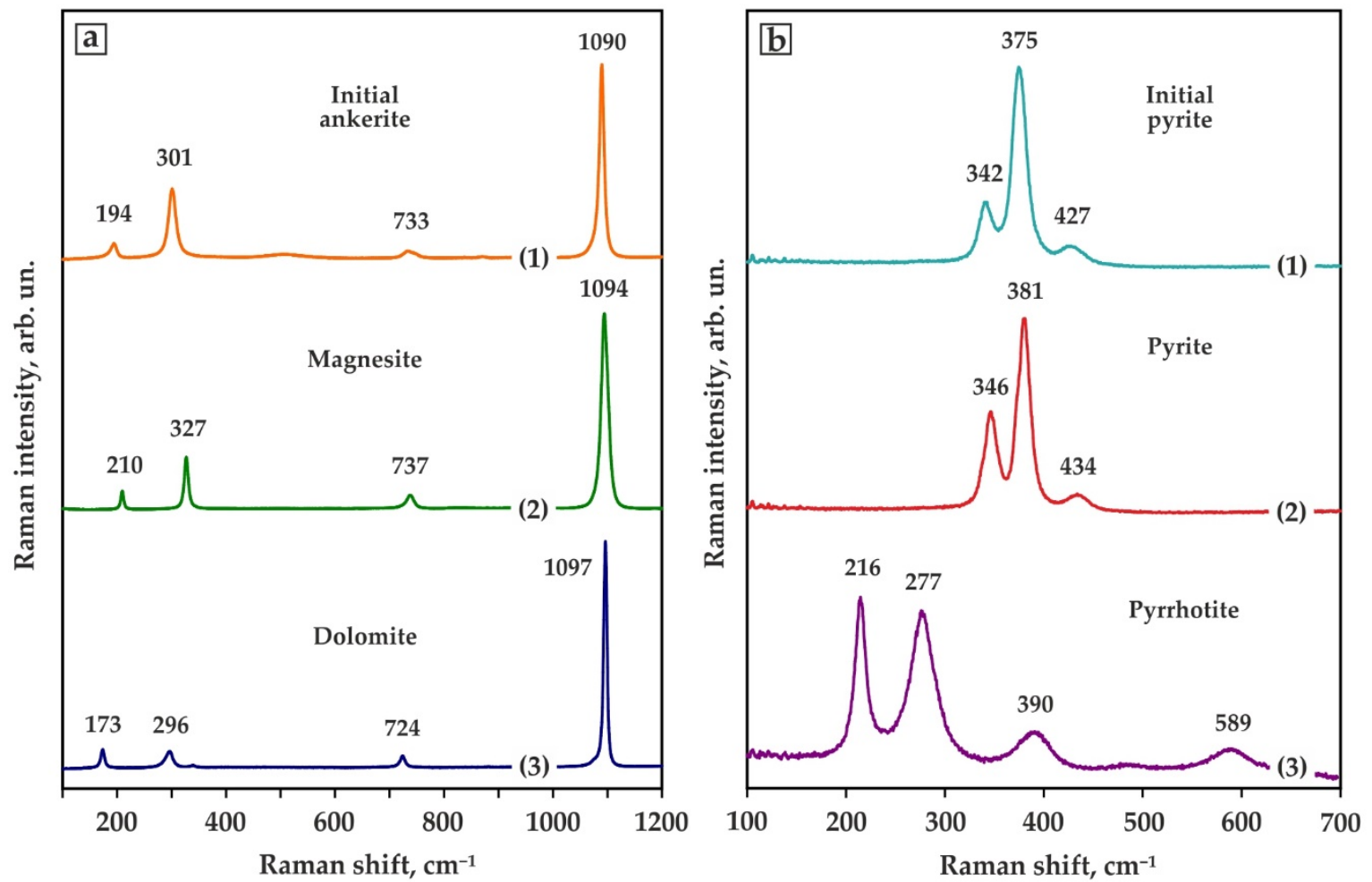

Figure 6. Representative Raman spectra: (a) initial natural ankerite (1), newly formed magnesite (1150 $\left.{ }^{\circ} \mathrm{C}\right)(2)$, and newly formed dolomite $\left(1350{ }^{\circ} \mathrm{C}\right)(3)$; (b) initial natural pyrite (1), recrystallized pyrite $\left(1050{ }^{\circ} \mathrm{C}\right)(2)$, and newly formed pyrrhotite $\left(1250^{\circ} \mathrm{C}\right)(3)$. arb. Un-arbitrary unit.

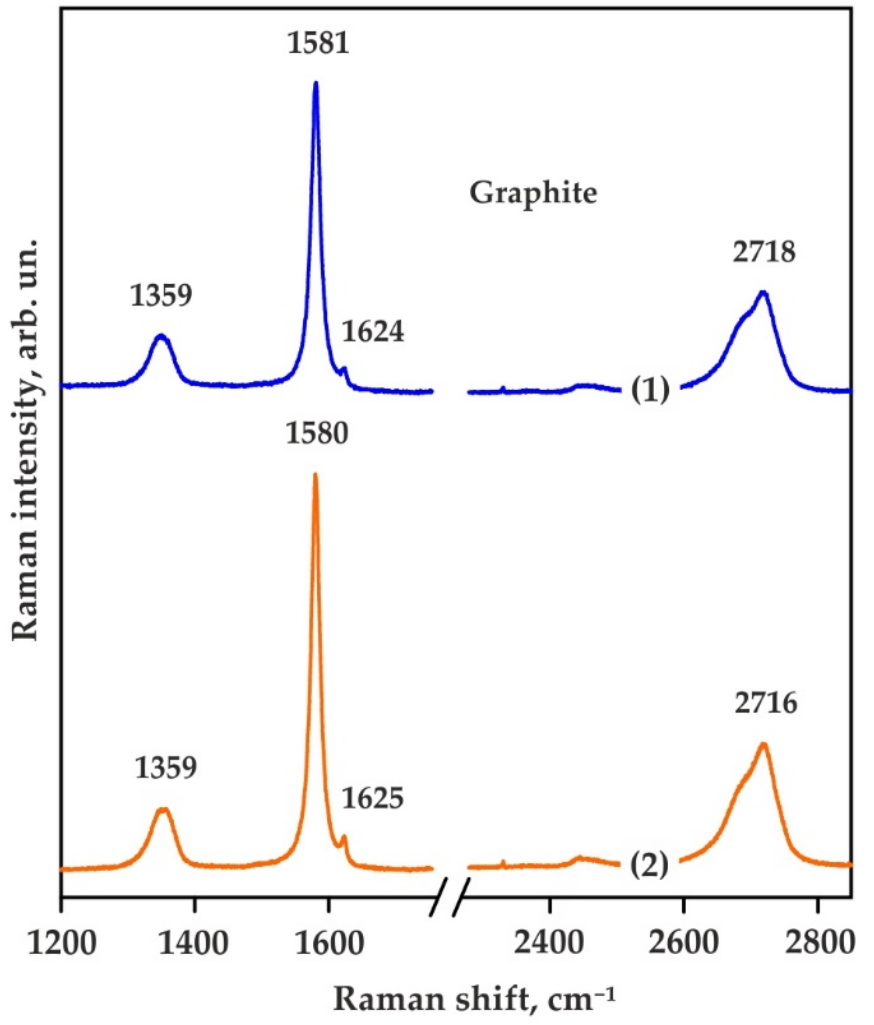

Figure 7. Representative Raman spectra of graphite: (1) $1150{ }^{\circ} \mathrm{C}$; (2) $1250^{\circ} \mathrm{C}$. / /: an interruption and continuation of the $\mathrm{x}$-axis values; arb.un.: arbitrary unit. 
The chemical compositions of the obtained phases are shown in Tables 2 and 3 . Dolomite is found in the samples only at $1350{ }^{\circ} \mathrm{C}$; it is characterized by FeO concentrations at the level of 2.7-3.0 wt. \%. At the contact of dolomite with sulfide melt, the formation of low or iron-free rims (edge parts) of carbonate crystals is observed. Magnesite is formed in the range of $1350-1450{ }^{\circ} \mathrm{C}$ and corresponds in composition to $\mathrm{Mg}_{0.86} \mathrm{Ca}_{0.05} \mathrm{Fe}_{0.02} \mathrm{CO}_{3}$. The quenched aggregates of the sulfide melt are represented by microdendrites of pyrite and pyrrhotite, and the bulk composition of the melt is characterized by the atomic ratio Fe:S = 0.99-1.1, as well as the content of dissolved oxygen from 0.6 to $2.0 \mathrm{wt}$. \%. The composition of the carbonate melt depends on the temperature; an increase in $\mathrm{Mg} \#$ (from 0.03 to 0.14 ) and iron content (from 0.25 to 0.48 ), as well as a decrease in Ca \# (from 0.72 to 0.39 ), occur when the temperature rises from 1350 to $1550{ }^{\circ} \mathrm{C}$ (Table 2).

\section{Discussion}

\subsection{Reconstruction of Ankerite-Pyrite Interaction Processes at Mantle P-T Parameters}

An analysis of the experimental results has shown that even at relatively low temperatures $\left(1050-1250^{\circ} \mathrm{C}\right)$, at which pyrite is stable in the solid-phase state, ankerite in the presence of pyrite is unstable and enters into reactions. It was found that at the P-T parameters of the experiments during the interaction of ankerite and pyrite, iron is extracted from carbonate, which is accompanied by the enrichment of pyrite with iron and leads to the formation of pyrrhotite:

$$
3 \mathrm{CaFe}_{0.5} \mathrm{Mg}_{0.5}\left(\mathrm{CO}_{3}\right)_{2}+\mathrm{FeS}_{2} \rightarrow 2 \mathrm{FeS}+2(\mathrm{Mg}, \mathrm{Fe}) \mathrm{Ca}\left(\mathrm{CO}_{3}\right)_{2}+2(\mathrm{Mg}, \mathrm{Ca}) \mathrm{CO}_{3}
$$

This process (extraction of iron from carbonate) initiates the decomposition of ankerite into dolomite and magnesite with $\mathrm{FeO}$ and $\mathrm{CaO}$ impurities. Considering that with an increase in temperature in the range of $1050-1250{ }^{\circ} \mathrm{C}$, the bulk concentration of $\mathrm{FeO}$ in dolomite decreases by more than 3 times, it can be assumed that, in relatively hightemperature experiments, the extraction of iron into sulfide occurs from the initial ankerite, but also from the newly formed FeO-bearing dolomite. Additional confirmation of the implementation of this process is the formation of large crystals of dolomite with a zonal structure, which manifests itself mainly at the contact of dolomite with sulfides and consists of the formation of low- or iron-free rims in its crystals. It has been experimentally established that newly formed pyrrhotite, dolomite, and magnesite, obtained as a result of ankerite-pyrite interaction at $\mathrm{T} \leq 1250{ }^{\circ} \mathrm{C}$, at subsequent stages of experiments, enter into carbon-producing redox reactions. According to these reactions, a small amount of metastable graphite is formed at the contact of carbonates and sulfides, while pyrrhotite is a reducing agent for the carbon of carbonates.

At temperatures above the solidus $\left(1350-1550{ }^{\circ} \mathrm{C}\right)$, the ankerite-pyrite interaction is accompanied by complete melting of the sulfide phase, as well as partial $\left(1350-1450{ }^{\circ} \mathrm{C}\right)$ or complete $\left(1550{ }^{\circ} \mathrm{C}\right)$ melting of carbonates. Under these conditions, all the processes described for relatively low temperatures are realized; however, elemental carbon-producing redox reactions occur much more intensively and are characterized by a number of features. At $\mathrm{T} \geq 1350{ }^{\circ} \mathrm{C}$, the formation of graphite and the growth of diamond at seeds occur as a result of the redox interaction of immiscible carbonate and sulfide melts, which can be described by the schematic reaction:

$(\mathrm{Ca}, \mathrm{Mg}, \mathrm{Fe}) \mathrm{CO}_{3 \text { liq }}+\mathrm{FeS}_{\mathrm{liq}} \rightarrow\left(\mathrm{Ca}, \mathrm{Mg}, \mathrm{Fe}_{1+\mathrm{x}}\right) \mathrm{CO}_{3 \text { liq }}+\mathrm{Fe}_{1-\mathrm{x}} \mathrm{S}_{-} \mathrm{O}_{\text {liq }}+\mathrm{C}^{0}$ graphite, diamond growth

With this redox interaction, the carbon of the carbonate melt is reduced to $\mathrm{C}^{0}$ (predominantly metastable graphite, \pm diamond growth), and the corresponding oxidation of the sulfide melt, accompanied by the dissolution of oxygen in it (Table 3). It should be emphasized that graphite crystals, in all cases, spatially confined to the contacts of sulfide and carbonate melts, as well as drops of sulfide melt on the surfaces of seed crystals with traces of diamond growth, are direct pieces of evidence of the implementation of this process in experiments. It was found that the medium for the crystallization of metastable 
graphite and the growth of diamond is a high-calcium carbonate melt, and the source of carbon is the initial ankerite. With an increase in temperature from 1350 to $1550{ }^{\circ} \mathrm{C}$ and a corresponding increase in the melting degree of carbonate phases, the intensity of $\mathrm{C}^{0}$-producing redox reactions increases, which is confirmed by an increase in the number of nucleation centers and the size of graphite crystals, the thickness of the overgrown diamond layer on the seeds, as well as an increase in the concentration of oxygen dissolved in a sulfide melt.

Thus, it was experimentally established that the main processes of interaction of ankerite and pyrite under mantle $\mathrm{P}-\mathrm{T}$ parameters should be considered (1) the extraction of iron from carbonate, accompanied by the enrichment of pyrite with iron and ultimately leading to the formation of pyrrhotite and the decomposition of ankerite into dolomite and magnesite and (2) redox reactions between newly formed pyrrhotite and $\mathrm{Mg}, \mathrm{Ca}, \mathrm{Fe}$ carbonates, leading to the formation of metastable graphite. Redox interaction of immiscible carbonate and sulfide melts is also a $\mathrm{C}^{0}$-producing process leading to graphite crystallization ( \pm diamond growth).

4.2. Implications of the Results of Ankerite-Pyrite Interaction to Graphite Formation via Ankerite Sulfidation in the Lithospheric Mantle and under Subduction Settings

The studied ankerite-pyrite interaction can be considered one of the potential processes that occur under conditions of crustal material subduction to mantle depths and are associated with a number of metasomatic transformations, as well as the formation of elemental carbon. It should be noted that ankerite itself is stable in a wide range of pressures and temperatures of the upper mantle [31] and can also be a product of the interaction of siderite and aragonite in the slab (Figure 1). According to studies devoted to the bulk estimates of the composition of the subducted rocks, as well as the redox budget of the subduction zones, pyrite is one of the most common minerals that concentrate sulfur in the subducting plate. Thermodynamic calculations [48] show that, under subduction conditions, pyrite is stable up to the parameters of the eclogite facies (pressure 5-6 GPa, depth 150-180 km), at greater depths, pyrite undergoes incongruent melting, with the formation of a sulfur melt and pyrrhotite. In this study, as well as in [43], we experimentally confirmed and supplemented the existing assumption of Tomkins and Evans [48] that under high-pressure conditions, a significant part of the subducted pyrite gradually transforms into pyrrhotite as a result of reactions $\mathrm{Fe}, \mathrm{Mg}$ silicates or Fe-bearing oxides according to the schematic reaction $\mathrm{FeS}_{2}+(\mathrm{Fe}, \mathrm{Mg}) \mathrm{O}_{\text {in silicates }}=2 \mathrm{FeS}+\mathrm{MgO}_{\text {in silicates }}$. Our data indicate that the enrichment of pyrite with iron and its transition to pyrrhotite can occur when interacting with iron-bearing carbonates, for example, with ankerite, according to a similar reaction. As a result of the extraction of iron from ankerite and violation of stoichiometry, this carbonate decomposes into magnesite and FeO-bearing dolomite, which, in turn, can also interact with pyrite. It is also interesting to note that at temperatures above $1350{ }^{\circ} \mathrm{C}(6.3 \mathrm{GPa})$, as a result of the ankerite-pyrite interaction, two immiscible melts are generated - carbonate and sulfide. These melts are considered as potential agents of mantle metasomatism-oxidating [49-54] and -reducing [55-61], respectively. The redox interaction of carbonate and sulfide melts under subduction conditions is a possible $\mathrm{C}^{0}$-producing process and also leads to the evolution of their compositions. In particular, in this process, as a result of the reduction of the carbonate component of the melt to $\mathrm{C}^{0}$, the balance of the number of divalent cations $(\mathrm{Mg}, \mathrm{Ca}, \mathrm{Fe})$ and carbonate ion is disturbed, which can lead to the crystallization of magnesian carbonates. Corresponding oxidation of the sulfide melt and the dissolution of a small amount of oxygen in it can also affect a number of its properties and change the buffer capacity. It was experimentally established that under the conditions of generation and interaction of two metasomatic agents-sulfide and carbonate melts - which can occur in a fairly wide range of temperatures and pressures in the subducting slab, graphite-producing redox reactions are predominantly realized. Thus, our studies have shown that ankerite-pyrite interaction, which can occur in a downgoing slab, involves ankerite sulfidation, triggers further graphite-forming redox reactions, and can be one of the scenarios of the elemental carbon formation under subduction settings. 
Author Contributions: Conceptualization, Y.V.B. and Y.N.P.; data curation, Y.V.B. and Y.N.P.; formal analysis, Y.V.B., I.D.N. and O.V.F.; funding acquisition, Y.N.P.; investigation, Y.V.B. and I.D.N.; methodology, Y.M.B.; project administration, Y.N.P.; visualization, Y.V.B. and O.V.F.; writing—original draft preparation, Y.V.B.; writing-review and editing, Y.N.P. All authors have read and agreed to the published version of the manuscript.

Funding: This work was supported by the Russian Science Foundation under Grant No. 19-17-00075. Data Availability Statement: Not Applicable.

Acknowledgments: The authors thank Evgeniy Zdrokov for his assistance in preparation of polished samples.

Conflicts of Interest: The authors declare no conflict of interest. The funders had no role in the design of the study; in the collection, analyses, or interpretation of data; in the writing of the manuscript, or in the decision to publish the results.

\section{References}

1. Stachel, T.; Harris, J.W. The origin of cratonic diamonds-Constraints from mineral inclusions. Ore Geol. Rev. 2008, 34, 5-32. [CrossRef]

2. Shirey, S.; Smit, K.; Pearson, D.; Walter, M.; Aulbach, S.; Brenker, F.; Bureau, H.; Burnham, A.; Cartigny, P.; Chacko, T.; et al. Diamonds and the mantle geodynamics of carbon: Deep mantle carbon evolution from the diamond record. In Deep Carbon: Past to Present; Orcutt, B., Daniel, I., Dasgupta, R., Eds.; Cambridge University Press: Cambridge, UK, 2019; pp. 89-128.

3. Shirey, S.B.; Cartigny, P.; Frost, D.J.; Keshav, S.; Nestola, F.; Nimis, P.; Pearson, D.G.; Sobolev, N.V.; Walter, M.J. Diamonds and the Geology of Mantle Carbon. Rev. Mineral. Geochem. 2013, 75, 355-421. [CrossRef]

4. Smith, E.M.; Shirey, S.B.; Nestola, F.; Bullock, E.S.; Wang, J.; Richardson, S.H.; Wang, W. Large gem diamonds from metallic liquid in Earth's deep mantle. Science 2016, 354, 1403-1405. [CrossRef] [PubMed]

5. Pal'yanov, Y.N.; Sokol, A.G.; Khokhryakov, A.F.; Pal'yanova, G.A.; Borzdov, Y.M.; Sobolev, N.V. Diamond and graphite crystallization in $\mathrm{COH}$ fluid at PT parameters of the natural diamond formation. Dokl. Earth Sci. 2000, 375, 1395-1398.

6. Palyanov, Y.N.; Bataleva, Y.V.; Sokol, A.G.; Borzdov, Y.M.; Kupriyanov, I.N.; Reutsky, V.N.; Sobolev, N.V. Mantle-slab interaction and redox mechanism of diamond formation. Proc. Natl. Acad. Sci. USA 2013, 110, 20408-20413. [CrossRef]

7. Palyanov, Y.N.; Borzdov, Y.M.; Khokhryakov, A.F.; Bataleva, Y.V.; Kupriyanov, I.N. Effect of sulfur on diamond growth and morphology in metal-carbon systems. CrystEngComm. 2020, 22, 5497-5508. [CrossRef]

8. Palyanov, Y.N.; Borzdov, Y.M.; Kupriyanov, I.N.; Bataleva, Y.V.; Nechaev, D.V. Effect of oxygen on diamond crystallization in metal-carbon systems. ACS Omega 2020, 5, 18376-18383. [CrossRef] [PubMed]

9. Stachel, T.; Brey, G.P.; Harris, J.W. Inclusions in sublithospheric diamonds: Glimpses of deep Earth. Elements 2005, 1, 73-78. [CrossRef]

10. Ryabchikov, I.D. Mechanisms of diamond formation: Reduction of carbonates or partial oxidation of hydrocarbons. Dokl. Earth Sci. 2009, 429, 1346-1349. [CrossRef]

11. Luth, R. Diamond formation during partial melting in the Earth's mantle. Abstr. Progr. Geol. Soc. Am. 2017, 49, 20-26.

12. Palyanov, Y.N.; Borzdov, Y.M.; Sokol, A.G.; Bataleva, Y.V.; Kupriyanov, I.N.; Reutsky, V.N.; Wiedenbeck, M.; Sobolev, N.V. Diamond formation in an electric field under deep Earth conditions. Sci. Adv. 2021, 7, eabb4644. [CrossRef]

13. Sverjensky, D.A.; Huang, F. Diamond formation due to a $\mathrm{pH}$ drop during fluid-rock interactions. Nat. Commun. 2015, 6, 8702. [CrossRef] [PubMed]

14. Wang, A.; Pasteris, J.D.; Meyer, H.O.A.; DeleDuboi, M.L. Magnesite-bearing inclusion assemblage in natural diamond. Earth Planet. Sci. Lett. 1996, 141, 293-306. [CrossRef]

15. Stachel, T.; Harris, J.W.; Brey, G.P. Rare and unusual mineral inclusions in diamonds from Mwadui, Tanzania. Contrib. Mineral. Petrol. 1998, 132, 34-47. [CrossRef]

16. Brenker, F.E.; Vollmer, C.; Vincze, L.; Vekemans, B.; Szymanski, A.; Janssens, K.; Szaloki, I.; Nasdala, L.; Joswig, W.; Kaminsky, F. Carbonates from the lower part of transition zone or even the lower mantle. Earth Planet. Sci. Lett. 2007, 260, 1-9. [CrossRef]

17. Wirth, R.; Kaminsky, F.; Matsyuk, S.; Schreiber, A. Unusual micro- and nanoinclusions in diamonds from the Juina Area, Brazil. Earth Planet. Sci. Lett. 2009, 286, 292-303. [CrossRef]

18. Logvinova, A.M.; Taylor, L.A.; Fedorova, E.N.; Yelisseyev, A.P.; Wirth, R.; Howarth, G.; Reutsky, V.N.; Sobolev, N.V. A unique diamondiferous peridotite xenolith from the Udachnaya kimberlite pipe, Yakutia: Role of subduction in diamond formation. Russ. Geol. Geophys. 2015, 56, 306-320. [CrossRef]

19. Izraeli, E.S.; Harris, J.W.; Navon, O. Fluid and mineral inclusions in cloudy diamonds from Koffiefontein, South Africa. Geochim. Cosmochim. Acta 2004, 68, 2561-2575. [CrossRef]

20. Kopylova, M.; Navon, O.; Dubrovinsky, L.; Khachatryan, G. Carbonatitic mineralogy of natural diamond-forming fluids. Earth Planet. Sci. Lett. 2010, 291, 126-137. [CrossRef]

21. Navon, O.; Hutcheon, I.D.; Rossman, G.R.; Wasserburg, G.J. Mantle-derived fluids in diamond microinclusions. Nature 1988, 335, 784-789. [CrossRef] 
22. Zedgenizov, D.A.; Ragozin, A.L.; Shatsky, V.S.; Araujo, D.; Griffin, W.L.; Kagi, H. Mg and Fe-rich carbonate-silicate high-density fluids in cuboid diamonds from the Internationalnaya kimberlite pipe (Yakutia). Lithos 2009, 112S, 638-647. [CrossRef]

23. Klein-BenDavid, O.; Logvinova, A.; Schrauder, M.; Spetius, Z.V.; Weiss, Y.; Hauri, E.H.; Kaminsky, F.V.; Sobolev, N.V.; Navon, O. High-Mg carbonatitic microinclusions in some Yakutian diamonds-A new type of diamond-forming fluid. Lithos 2009, 112, 648-659. [CrossRef]

24. Zedgenizov, D.A.; Ragozin, A.L.; Shatsky, V.S.; Araujo, D.; Griffin, W.L. Fibrous diamonds from the placers of the northeastern Siberian Platform: Carbonate and silicate crystallization media. Russ. Geol. Geophys. 2011, 52, 1298-1309. [CrossRef]

25. Weiss, Y.; Kiflawi, I.; Davies, N.; Navon, O. High-density fluids and the growth of monocrystalline diamonds. Geochim. Cosmochim. Acta 2014, 141, 145-159. [CrossRef]

26. Weiss, Y.; Griffin, W.L.; Bell, D.R.; Navon, O. High-Mg carbonatitic melts in diamonds, kimberlites and the sub-continental lithosphere. Earth Planet. Sci. Lett. 2011, 309, 337-347. [CrossRef]

27. Cartigny, P. Stable isotopes and the origin of diamond. Elements 2005, 1, 79-84. [CrossRef]

28. Yaxley, G.M.; Green, D.H. Experimental demonstration of refractory carbonate-bearing eclogite and siliceous melts in the subduction regime. Earth Planet. Sci. Lett. 1994, 128, 313-325. [CrossRef]

29. Dasgupta, R.; Hirschmann, M.M. The deep carbon cycle and melting in Earth's interior. Earth Planet. Sci. Lett. 2010, $298,1-13$. [CrossRef]

30. Walter, M.J.; Kohn, S.C.; Araujo, D.; Bulanova, G.P.; Smith, C.B.; Gaillou, E.; Wang, J.; Steele, A.; Shirey, S.B. Deep mantle cycling of oceanic crust: Evidence from diamonds and their mineral inclusions. Science 2011, 334, 54-57. [CrossRef]

31. Morlidge, M.; Pawley, A.; Droop, G. Double carbonate breakdown reactions at high pressures: An experimental study in the system $\mathrm{CaO}-\mathrm{MgO}-\mathrm{FeO}-\mathrm{MnO}-\mathrm{CO}_{2}$. Contrib. Mineral. Petrol. 2006, 152, 365-373. [CrossRef]

32. Logvinov, V.M.; Doroshev, A.M. Phase change in $\mathrm{Mg}, \mathrm{Ca}, \mathrm{Sr}$ and Ba carbonates at pressures to 160 kbar. In High-Pressure Silicate Systems; IGiG SO AN SSSR: Novosibirsk, Russia, 1983; pp. 47-56. (In Russian)

33. Shatskiy, A.F.; Litasov, K.D.; Palyanov, Y.N. Phase relations in carbonate systems at pressures and temperatures of lithospheric mantle: Review of experimental data. Russ. Geol. Geophys. 2015, 56, 113-142. [CrossRef]

34. Sharp, W.E. Melting curves of sphalerite, galena, and pyrrhotite and the decomposition curve of pyrite between 30 and 65 kilobars. J. Geophys. Res. 1969, 74, 1645-1652. [CrossRef]

35. Arima, M.; Kozai, Y.; Akaishi, M. Diamond nucleation and growth by reduction of carbonate melts under high-pressure and high-temperature conditions. Geology 2002, 30, 691-694. [CrossRef]

36. Siebert, J.; Guyot, F.; Malavergne, V. Diamond formation in metal-carbonate interactions. Earth Planet. Sci. Lett. 2005, 229, 940-950. [CrossRef]

37. Yamaoka, S.; Shaji Kumar, M.D.; Kanda, H.; Akaishi, M. Formation of diamond from $\mathrm{CaCO}_{3}$ in a reduced C-O-H fluid at HP-HT. Diam. Relat. Mater. 2002, 11, 1496-1504. [CrossRef]

38. Pal'yanov, Y.N.; Sokol, A.G.; Borzdov, Y.M.; Khokhryakov, A.F.; Sobolev, N.V. Diamond formation through carbonate-silicate interaction. Am. Miner. 2002, 87, 1009-1013. [CrossRef]

39. Bataleva, Y.V.; Palyanov, Y.N.; Borzdov, Y.M.; Novoselov, I.D.; Bayukov, O.A. An effect of reduced S-rich fluids on diamond formation under mantle-slab interaction. Lithos 2019, 336-337, 27-39. [CrossRef]

40. Gunn, S.C.; Luth, R.W. Carbonate reduction by Fe-S-O melts at high pressure and high temperature. Am. Miner. 2006, 91, 1110-1116. [CrossRef]

41. Palyanov, Y.N.; Borzdov, Y.M.; Bataleva, Y.V.; Sokol, A.G.; Palyanova, G.A.; Kupriyanov, I.N. Reducing role of sulfides and diamond formation in the Earth's mantle. Earth Planet. Sci. Lett. 2007, 260, 242-256. [CrossRef]

42. Bataleva, Y.V.; Palyanov, Y.N.; Borzdov, Y.M.; Kupriyanov, I.N.; Sokol, A.G. Synthesis of diamonds with mineral, fluid and melt inclusions. Lithos 2016, 265, 292-303. [CrossRef]

43. Zdrokov, E.; Novoselov, I.; Bataleva, Y.; Borzdov, Y.; Palyanov, Y. Experimental modeling of silicate and carbonate sulfidation under lithospheric mantle P, T-parameters. Minerals 2019, 9, 425. [CrossRef]

44. Palyanov, Y.N.; Borzdov, Y.M.; Khokhryakov, A.F.; Kupriyanov, I.N.; Sokol, A.G. Effect of Nitrogen Impurity on Diamond Crystal Growth Processes. Cryst. Growth Des. 2010, 10, 3169-3175. [CrossRef]

45. Sokol, A.G.; Borzdov, Y.M.; Palyanov, Y.N.; Khokhryakov, A.F. High-temperature calibration of a multi-anvil high pressure apparatus. High Press. Res. 2015, 35, 139-147. [CrossRef]

46. Palyanov, Y.N.; Sokol, A.G. The effect of composition of mantle fluids/melts on diamond formation processes. Lithos 2009, 112, 690-700. [CrossRef]

47. Dasgupta, R.; Buono, A.; Whelan, G.; Walker, D. High-pressure melting relations in Fe-C-S systems: Implications for formation, evolution, and structure of metallic cores in planetary bodies. Geochim. Cosmochim. Acta 2009, 73, 6678-6691. [CrossRef]

48. Tomkins, A.; Evans, K.A. Separate zones of sulfate and sulfide release from subducted mafic oceanic crust. Earth Planet. Sci. Lett. 2015, 428, 73-83. [CrossRef]

49. Wallace, M.; Green, D.H. An experimental determination of primary carbonatite composition. Nature 1988, 335, 343-345. [CrossRef]

50. Wyllie, P.J.; Ryabchikov, I.D. Volatile components, magmas and critical fluids in upwelling mantle. J. Petrol. 2000, 41, 1195-1206. [CrossRef] 
51. Kamenetsky, M.B.; Sobolev, A.V.; Kamenetsky, V.S.; Maas, R.; Danyushevsky, L.V.; Thomas, R.; Pokhilenko, N.P.; Sobolev, N.V. Kimberlite melts rich in alkali chlorides and carbonates: A potential metasomatic agent in the mantle. Geology 2004, 32, 845-848. [CrossRef]

52. Kelley, K.A.; Cottrell, E. Water and the oxidation state of subduction zone magmas. Science 2009, 325, 605-607. [CrossRef]

53. Foley, S.F. A reappraisal of redox melting in the Earth's mantle as a function of tectonic setting and time. J. Petrol. 2011, 2 1363-1391. [CrossRef]

54. O'Reilly, S.Y.; Griffin, W.L. Mantle metasomatism. In Metasomatism and the Chemical Transformation of Rock. The Role of Fluids in Terrestrial and Extraterrestrial Processes; Harlov, D.E., Austrheim, H., Eds.; Springer: Berlin/Heidelberg, Germany, 2013 ; pp. 471-533.

55. Alt, J.C.; Shanks, W.C.; Jackson, M.C. Cycling of sulfur in subduction zones: The geochemistry of sulfur in the Mariana-Island Arc. Earth Planet. Sci. Lett. 1993, 119, 477-494. [CrossRef]

56. Jégo, S.; Dasgupta, R. The fate of sulfur during fluid-present melting of subducting basaltic crust at variable oxygen fugacity. J. Petrol. 2014, 55, 1019-1050. [CrossRef]

57. Labidi, J.; Cartigny, P.; Jackson, M.G. Multiple sulfur isotope composition of oxidized Samoan melts and the implications of a sulfur isotope 'mantle array' in chemical geodynamics. Earth Planet. Sci. Lett. 2015, 417, 28-39. [CrossRef]

58. Lorand, J.-P.; Grégoire, M. Petrogenesis of base metal sulphide assemblages of some peridotites from the Kaapvaal craton (South Africa). Contrib. Mineral. Petrol. 2006, 151, 521-538. [CrossRef]

59. Andersen, T.; Neumann, E. Fluid inclusions in mantle xenoliths. Lithos 2001, 55, 301-320. [CrossRef]

60. Newton, R.C.; Manning, C.E. Solubility of anhydrite, $\mathrm{CaSO}_{4}$, in $\mathrm{NaCl}-\mathrm{H}_{2} \mathrm{O}$ solutions at high pressures and temperatures: Applications to fluid-rock interaction. J. Petrol. 2005, 46, 701-716. [CrossRef]

61. Giuliani, A.; Phillips, D.; Fiorentini, M.L.; Kendrick, M.A.; Maas, R.; Wing, B.A.; Woodhead, J.D.; Bui, T.H.; Kamenetsky, V.S. Mantle oddities: A sulphate fluid preserved in a MARID xenolith from Bultfontein kimberlite (South Africa). Earth Planet. Sci. Lett. 2013, 376, 74-86. [CrossRef] 